\title{
Unequal Developments in Indonesia's Digital-Based Economy and Its Implications
}

\author{
Sri Adiningsih ${ }^{\mathrm{a}, *}$, Stri Nariswari Setiaji ${ }^{\mathrm{b}}$, \& Sofian Rendy Ardiansyah ${ }^{\mathrm{c}}$ \\ ${ }^{a}$ Chair of the Presidential Advisory Council \& Gadjah Mada University \\ ${ }^{b}$ Independent Economist \\ ${ }^{c}$ Staff at the Presidential Advisory Council
}

\begin{abstract}
Despite having emerged for just some years, the development and growth of the digitalbased economy in Indonesia is exponential. This study uses the Purposive Random Sampling and Descriptive Analyses method to assess the developments of the digital-based economy in several provinces in Indonesia. The Java-Bali region is more advanced in its digital-based economy compared to other provinces in Indonesia due to its infrastructure, human resources, and government policies which are more supportive. The inequalities between provinces remain a concern for it may directly correlate to a corresponding increase in disparity. Digital-based economy, if it is well-equipped with infrastructure and well-supported by local government, may serve as a balm given its potential as a tool to raise prosperity and equality in society. It will help prepare and equip those in remote rural areas, known as the bottom of the pyramid.
\end{abstract}

Keywords: digital-based economy; inequality; the bottom of the pyramid JEL Classification: $\mathrm{O} 1 ; \mathrm{O} 31 ; \mathrm{O} 33$

\footnotetext{
*The authors express gratitude to Erna Maria Lokollo, Canyon Keanu Can, and Umi Fitria Ridya Rachmawaty for all their help in the making of this paper.

Corresponding Author: Gadjah Mada University. E-mail: sadining@gmail.com.
} 


\section{Introduction}

Disruptive Innovations, also widely known as the Industrial Revolution 4.0, are profoundly changing all aspects of our lives from all locations across the globe. The fundamental disruptions which occur can shatter the old ways of economy, business, societal relations, laws, politics, defense and security, as well as public service. In Indonesia, these changes have breached all aspects of life in both urban and remote rural areas, albeit with unequal distribution due to Indonesia's massive size of 16,050 islands and a population of 265 million in 2018 (BPS, 2018).

Disruptive innovations emerge together with new eras called Industrial Revolutions. To date, there have been four Industrial Revolutions, each of them spreading and changing human lives at an increasingly rapid speed than their predecessor. The Industrial Revolution 1.0 occurred in 1750-1850 with the invention of water and steam power, which increased production efficiency because it replaced human and animal power. Similarly, the Industrial Revolution 2.0 occurred in 1870-1919 with the discovery of electricity, followed by the Industrial Revolution 3.0 between 1969-2011 with the rise of the internet and automated systems amidst people's lives. Finally, the ongoing Industrial Revolution 4.0 which began in 2012 was sparked by the invention of cyber-physical systems that allowed for new innovations such as driverless/autonomous vehicles, smart robots, lighter but stronger materials, and manufacturing processes using 3D printing, all of which are spreading swiftly (World Economic Forum, 2016). All these advancements are made possible by developments in 4 types of existing technologies. Those four technologies are Mobile Internet that enables smart phones to utilize the internet, Cloud Computing that enables easier and relatively cheaper access and connectivity to information, the Internet of Things that enables business growth and new methods of production, and Big Data and Advanced Analytics that enables more efficient processing of information. All these changes and developments occur in every aspect of human life, evolving quickly and benefitting people immensely (McKinsey Global Institute, 2016).

The ongoing digitalization of the economy initially began to accelerate with developments in e-commerce/online shopping (with goods ranging from basic necessities to cars and houses) in Indonesia. Then, the burgeoning of on-demand services such as online transportation and logistics (Grab and Gojek), online travel (traveloka, tiket.com), online food and drink (Berrykitchen), online education (ruangguru, bahaso), and financial technology (P2P Lending- Investree, Crowdfunding- Kitabisa.com, Payment- Gopay, Blockchain, and other banking services). Other technological innovations (3D Printing, drones, robotics, automation, and driverless vehicles) also currently start to develop. The Industrial Revolution 4.0's significant impacts to the economy and businesses include increases in efficiency and new methods of production at each chain of supply, and the development of the sharing economy. The general public also experiences the impacts of the Industrial Revolution 4.0 through changes such as faster access to information, shifts in fields of work, and losses in privacy (Adiningsih et al., 
2019).

It is hoped that the developments in the digital-based economy will be able to raise the prosperity of Indonesia's societies if it is well anticipated and responded. Therefore, it is important for us to understand well the ongoing developments in Indonesia's digital-based economy and their implications.

\section{Literature Review}

\subsection{Digital-Based Economic Developments in the World}

The exponentially developing digital-based economy has vast impacts on people's lives. Although the First to the Fourth Industrial Revolutions throughout the world has been getting faster lately, the numerous changes, advancements, and increases in the world's prosperity that they brought about are still unevenly distributed. Many countries or societies can swiftly capture the potential and opportunities the Revolutions present, but there are also those who lag behind. Until today, there remain countries, regions, and societies living in the lifestyle of the Industrial Revolution 3.0, and even some still undergoing 1.0, though the majority already utilizes 4.0 . Those changes in patterns of living contribute to the inequalities in society, from Society 1.0 (societies still in the hunting-gathering era) to Society 5.0 (super smart societies) (Adiningsih et al., 2019). The following figure illustrates the First to the Fourth Industrial Revolution.

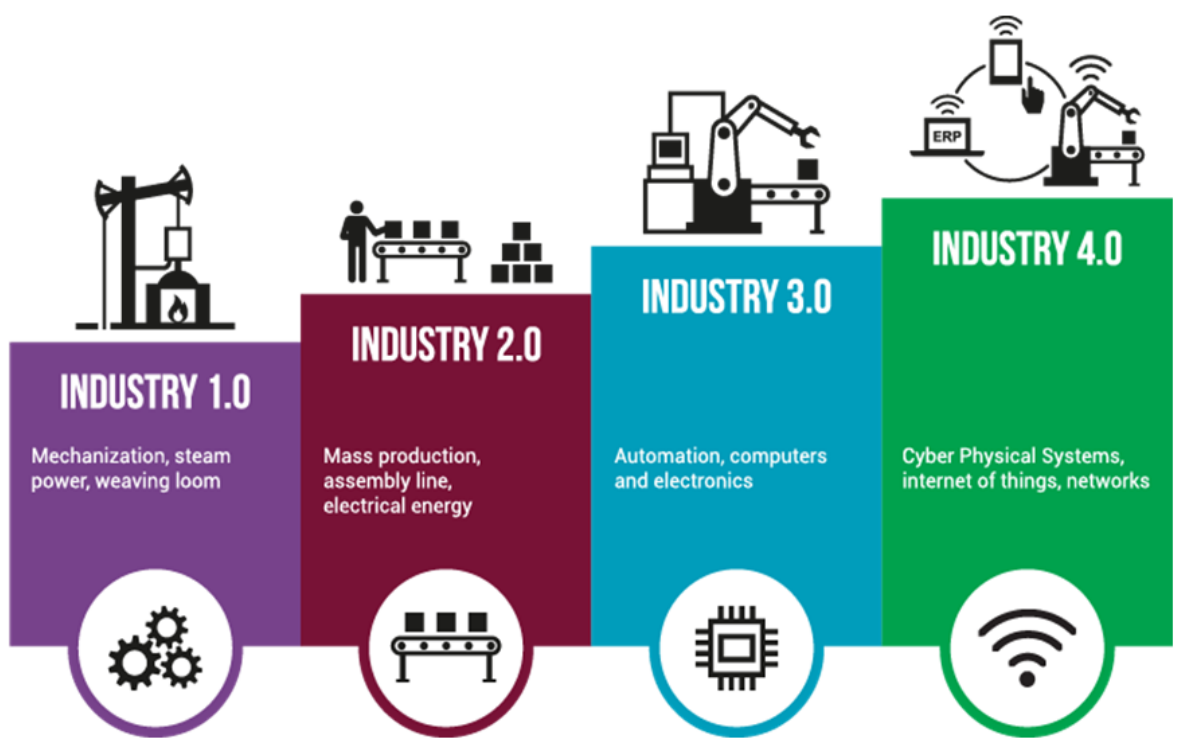

Figure 1: The First to the Fourth Industrial Revolution

Source: World Economic Forum (2016) 
The digital-based economy is the unavoidable economy of the future. If it is anticipated, responded to, and managed well, it then will develop even faster to bring the promise of progress and prosperity for all. As such, many countries have acted to expediently anticipate and respond to the current transformation so are to reap the benefits of its immense potential. Several developing and developed countries such as Australia, the People's Republic of China (PRC), the United States, the United Arab Emirates, and India possess special units, as Ministries or Agencies, which function to support and facilitate readiness and advancements in the digital transformation. Australia established its Digital Transformation Agency (DTA) to help the Prime Minister conduct studies regarding the digital transformation. The People's Republic of China has two Ministries tasked with smoothing the transformation into the digital era, and they are the Ministry of Science and Technology and the Ministry of Industry and Information Technology. Meanwhile, the United States has the US Digital Service which provides better government services through the application of technology, and the United Arab Emirates has a Minister of State for Artificial Intelligence among the country's cabinet members, and India has the Digital India program (Adiningsih et al., 2019). The Government of Indonesia also participates through the making of various policies to respond to and anticipate developments in the digital-based economy.

One characteristic of the Industrial Revolution 4.0 is the emergence of disruptive innovations. Disruptive technologies force us all to adapt. In particular, business actors are under high pressure to alter themselves; otherwise, they will face increasingly difficult challenges or even go out of business as victims of the relentless change. An example is the rise of applications for online purchases of travel tickets which have resulted in the decline of the travel agency business; the rise of e-commerce has also caused the fall in revenues and the bankruptcy of numerous offline stores. Similarly, conventional banks must also adapt by entering the digital world, or Fintech, if they desire to survive and develop (Adiningsih et al., 2019).

\subsection{Digital-Based Economic Developments in Indonesia}

Indonesia is among the countries who have taken advantage of the digital-based economy, with rapid growth despite only beginning to become digital in 2015, a year marked by the appearance of e-commerce (Tokopedia and Bukalapak) and online transportation (Gojek and Grab) startups. Some of those companies have now become unicorns, and Gojek has even become a Decacorn. Moreover, financial technology has also rapidly developed, with 116 Fintech companies already registered in the Financial Services Authority (Otoritas Jasa Keuangan, or the OJK) (OJK, 2019), some of them having grown considerably, such as Investree, Bareksa, and Payfazz. These advancements in the digital-based economy are supported by the increasing electrification rate which reached 99.98 percent in 2019 and internet access which has risen and become more equally distributed 
in the past several years alongside developments in the Palapa Ring project (which only awaits Eastern Indonesia, where the project has reached 92 percent completion) and in the Sideka program which aims to bring internet into villages and which has reached over six thousand villages (Adiningsih et al., 2019).

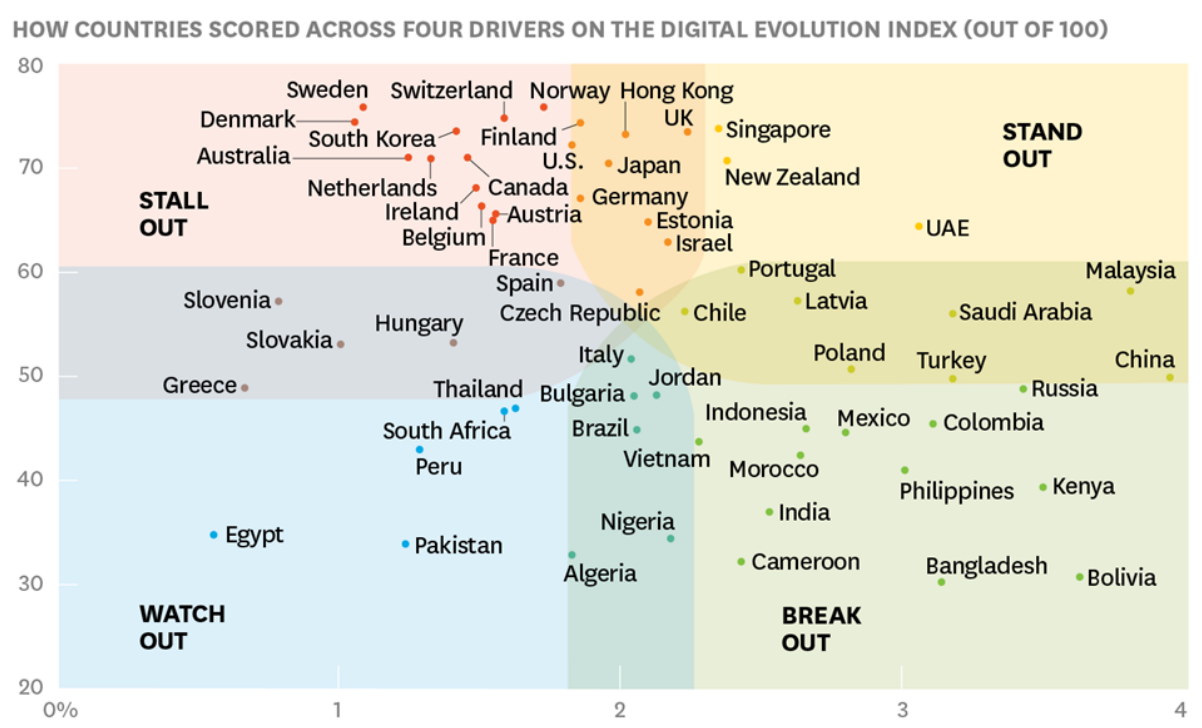

Figure 2: Graph of the Digital Evolution Index

Source: Tufts University (2017)

According to the IMD World Competitiveness Report (2017), Indonesia's competitiveness in adopting and exploring digital technology for transformation in its government, business models, and society is still considered low (ranked 59 out of 63 countries). This is due to the low level of investment into Human Resources (HR) in the field of digital technology. Yet, nearly half of Indonesia's population uses the internet (126 million people), with the digitally savvy millennial population (a third of Indonesia's population, equivalent to 83 million people) dominating the majority of internet users (Kemenppa, 2017). As such, Indonesia is found within the Break Out quadrant of the Digital Evolution Index, a position parallel with the People's Republic of China (PRC), as a country with a low digital adoption score but with fast evolution so that it has the potential to become a country with a strong digital-based economy. McKinsey Global Institute's (2016) data supports this by showing that Indonesia has already utilized Mobile Internet, the Cloud, the Internet of Things, and Big Data. The following shows the figures adoption of disruptive technologies in Indonesia.

Indonesia has immense potential in reaping the benefits of the digital-based economy as it already possesses adequate infrastructure. Indeed, the digitalbased economy has experienced extraordinary growth in the past few years. 

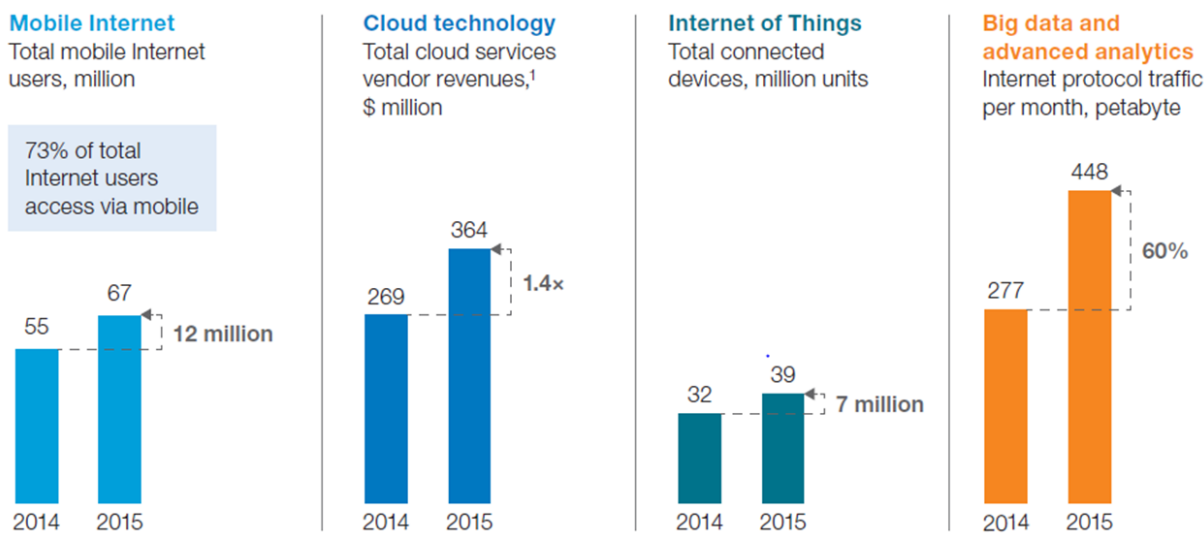

Figure 3: Adoption of Disruptive Technologies in Indonesia

Source: McKinsey Global Institute \& Company (2016)

Numerous e-commerce, sharing economy, financial technology, and on-demand services startups have appeared, some receiving funds from investors which have allowed several of them to become unicorns. In the meantime the startups have formed associations such as IDEA (Indonesia e-Commerce Association) and AFTECH (Asosiasi Fintech Indonesia) to foster relationships with the government and between actors in the digital-based economy.

The government continuously anticipates and responds to those swift developments in the digital-based economy. The fostering and regulation of the digital-based economy falls beneath several Ministries and Agencies, including the Ministry of Communication and Information (Kominfo), the Coordinating Ministry for Economic Affairs (Kemenko Perekonomian), the Ministry of Transportation (Kemenhub), the Financial Service Authority (Otoritas Jasa Keuangan/OJK), The Central Bank of Indonesia (Bank Indonesia/BI), the Creative Economy Agency (Bekraf), and the Ministry of Trade (Kemendag). Several regulations related to the digital-based economy which have been issued include Presidential Decree on the E-Commerce Road Map 2017-2019 (Perpres Nomor 74 Tahun 2017 Tentang Peta Jalan Sistem Perdagangan Nasional Berbasis Elektronik (Road Map E-commerce) Tahun 2017-2019), the Decree of the Minister of Trade of the Republic of Indonesia on General Policies for Carrying Out Crypto Futures Trading (Peraturan Menteri Perdagangan RI No. 99 Tahun 2018 tentang Kebijakan Umum Penyelenggara perdagangan Berjangka Aset Kripto), the Decree of the Minister of Transportation on Taxi-bikes (Ojek Online) on Safety Protections for Motorbike Users for the Public Interest (Peraturan Menteri Perhubungan terkait Ojek No. 12 Tahun 2019 tentang Perlindungan Keselamatan Pengguna Sepeda Motor yang Digunakan untuk Kepentingan Masyarakat), the OJK Regulation on Digital Finance Innovations in the Financial Sector (POJK No. 13/POJK.02/2018 tentang Inovasi Keuangan Digital di sektor Jasa 
Keuangan), the BI Regulation on the Implementation of Financial Technology (PBI no 19/12/PBI/2017 tentang Penyelenggaraan Teknologi Finansial), and many more. Naturally, various other lower regulations have also been issued by local governments (Adiningsih et al., 2019).

We must anticipate and respond well to the digital-based economy development, not merely to reduce poverty and inequality but also to raise people's prosperity and create new and more employment. McKinsey Global Institute's (2018) study estimates that, in Indonesia, automation will result in the loss of 23 million jobs, but simultaneously has the potential to create 46 million new jobs by 2030. Another McKinsey Global Institute (2017) report also estimates that e-commerce has the potential to increase jobs by 26 million by 2025 in Indonesia. At this time, the development of a digital-based economy has created many jobs such as Tokopedia and Bukalapak in which currently able to host 5 million merchants each on their respective platforms (in Tokopedia itself, as many as 70 percent of the merchants are newcomers), and over 1.5 million drivers have joined Gojek across Indonesia. Thus, it is evident that the digital-based economy offers vast benefits if utilized properly. Therefore, as we progress forward, the Indonesia Go Digital 2020 target is no longer a far-fetched dream.

This paper is made to explain the developments in the digital-based economies of eight provinces in Indonesia, followed by implications regarding the issues which must be addressed in order to successfully compete in the digital era.

\section{Method}

The method used in the making of this paper is Purposive Random Sampling - Descriptive Analyses through various discussions with experts, surveys, and direct field visits. Purposive Random Sampling was chosen by the researchers because it allowed us to determine sampling by specifying characteristics in accordance with research objectives so as to answer the existing research problems. According to Neuman (2014), Purposive Random Sampling is a sampling technique based on randomness, regions, or clusters, and on considerations that focus on specific objectives.

From a total of 34 provinces, researchers took a sample of 8 chosen provinces in Indonesia: the Special Capital Region of Jakarta, West Java, the Special Region of Yogyakarta, Bali (which represents the Java-Bali region), Central Kalimantan, North Sumatra, East Nusa Tenggara, and South Sulawesi (which represents regions outside of the Java-Bali region). The eight provinces were chosen as the sample used due to various main indicators: the researchers desired to understand the extreme gap/level of disparity between provinces with high readiness in the digital-based economy and those with low readiness. Therefore, purposive sampling was conducted to ensure that the sample chosen would be consistent with the research objectives.

For each of the provinces studied, the researchers also used the descriptive analytics approach where conclusions drawn can only be applied to the data used, 
without generalizations to wider scopes of data.. The research was conducted over a period of two years, during which the researchers visited each of the eight sampled provinces. In each province, researchers met with local governments, startups, relevant training and education institutions, communities, business actors. The researchers also met and held discussions with officials, associations, and stakeholders at the central government level. Finally, data on internet access for each province cannot be obtained so it is proxyed with the percentage of households accessing the internet in the last 3 months.

\section{Result}

This study was conducted on eight provinces in Indonesia, four of them being in the Java-Bali region (DKI, West Java, DI Yogyakarta, and Bali) where infrastructure to support digitalization is relatively advanced and human resources are of higher quality, and the other four being the provinces of Central Kalimantan, South Sulawesi, East Nusa Tenggara, and North Sumatra, which are relatively lagging. It was found that the provinces in Java and Bali are generally more advanced and have more support from local government policies on the digitalbased economy, resulting in better development of the digital-based economy. Meanwhile, provinces outside of Java and Bali are generally left behind in terms of infrastructure and human resources quality, and provincial governments have not yet supported the development of the digital-based economy, leading to less development in the digital-based economy. The following present findings will focus on Jakarta, Yogyakarta, South Sulawesi, and Central Kalimantan, which shows the imbalance of digital-based economic developments in Indonesia.

Jakarta is unique as the capital city of the country and as the center of economic activity in Indonesia, thus greatly benefiting from being able to attract resources and utilize all government policies from the central government that support the development of a digital-based economy. From the existing findings, Jakarta is among the provinces with excellent digital readiness compared to other provinces in the research sample. Generally, Jakarta has a strong digital-based economy. This is mirrored in the local government's policies regarding digital matters, basic infrastructure, developments in the ecosystem for digital-based startups, and digital-related education. Jakarta has issued various digital-related regulations, such as on the use of digital electronics, the Jakarta One system, the implementation of electronic revenue collection, guidelines for encryption to protect information, and many more. Meanwhile, Jakarta's basic infrastructure is already adequate, as seen from its 100 percent electrification ratio and high percentage of households accessing the internet ( 85.70 percent), the highest from all 8 provinces sampled. Jakarta's startup ecosystem has also developed rapidly, as indicated by the number of digital startups in the province which far exceeds all other provinces, the presence of many incubators and accelerators, and the existence of many co-working spaces for startup communities to meet and interact in. Finally, Jakarta is one of the provinces with the most advanced digital-related 


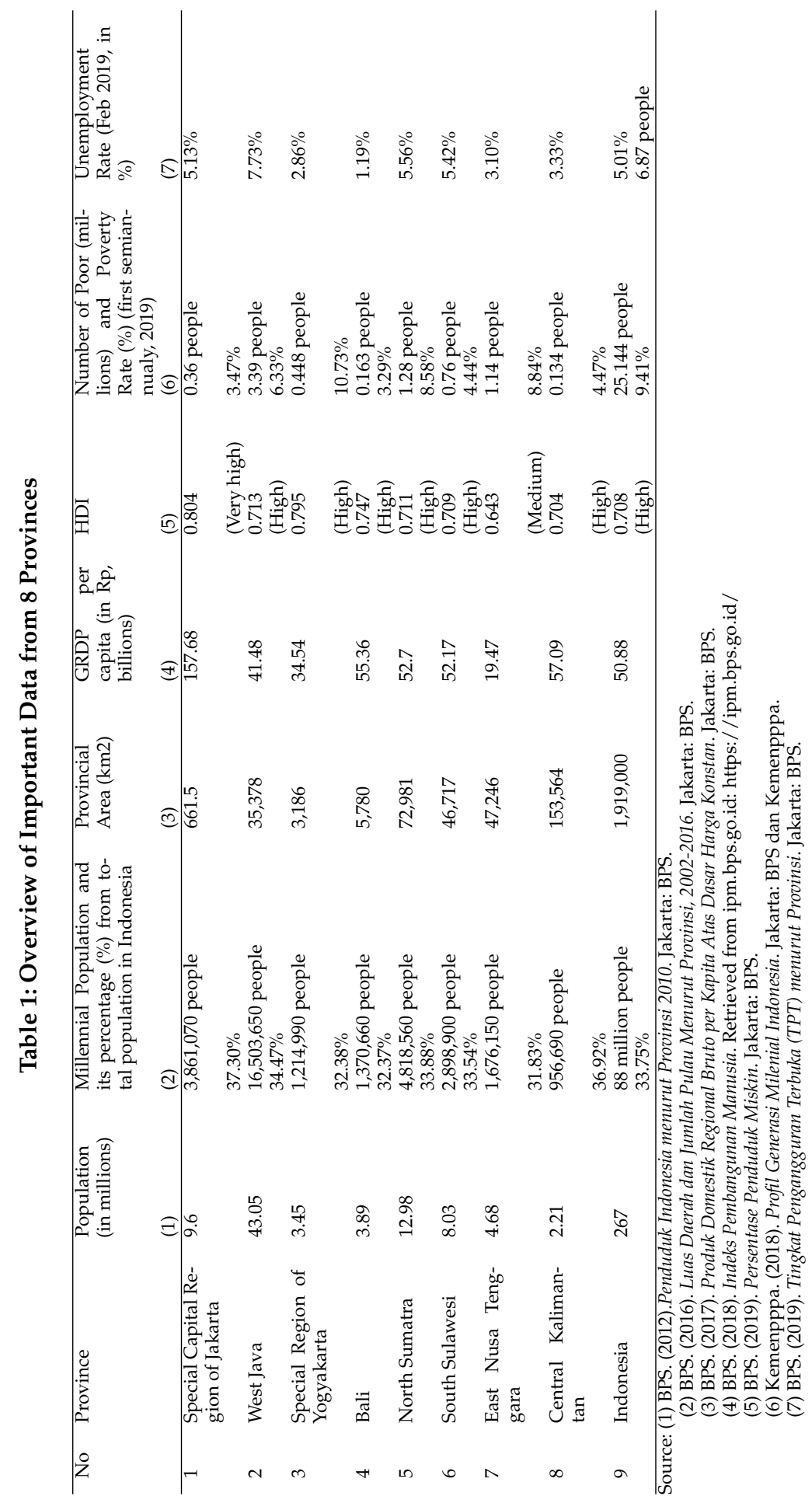


education, having many higher and middle level education institutions focusing on digital matters. This is evidenced by the presence of digital-related majors which can only be found in Jakarta; for example, Mobile Application and Technology, and Game Application and Technology from Universitas Bina Nusantara, as well as Avionics Electric Instruments Engineering from SMKN 29. Although Jakarta is a relatively small area at only $661.5 \mathrm{~km}^{2}$, its large high quality population becomes one of its sources for the development of its digital-based economy. The province of Jakarta itself has the highest percentage of millennials, 37.30 percent, from all the provinces sampled. Jakarta also has the highest GRDP per capita at 157 million Rupiahs, and a very high Human Development Index at 0.804 , in line with its low poverty at 3.47 percent or equivalent to 365 thousand people.

Yogyakarta, West Java, and Bali experience rapid developments in their digital-based economies due to supportive government policies, better infrastructure, and their well-developed quality of HR which allows startups to grow and flourish, even if there are not yet any unicorn startups from the regions. The Special Region of Yogyakarta has adequate basic infrastructure and a flourishing digital-based economy, but its poverty is very high. The following explanations on several indicators regarding government regulations, digital-related basic infrastructure, startup developments, and digital-related education sheds light on the province's progress. In general, the Local Government of Yogyakarta has captured well the potential of digital developments in Indonesia, issuing many regulations regarding digital matters such as on the operation of informationtechnology-based taxi and rental transportation, information security management systems, control of telecommunication towers and fiber optics, and many more. Moreover, evidence of Yogyakarta's ample basic infrastructure is its electrification ratio that is on par with Jakarta's at over 100 percent, and its relatively high percentage of households accessing the internet at 71.71 percent, the second highest after Jakarta. These findings are in line with the growth of the startup ecosystem in Yogyakarta. The Indonesian Startup Database and the researchers' own findings from a field visit to Yogyakarta show that the number of startups developing in Yogyakarta is large. Yogyakarta's number of startup incubators is also high, nearly similar with the number in West Java. There exist a considerable number of co-working spaces in Yogyakarta too. Furthermore, Yogyakarta performs well with regards to its digital-related education, having several universities and national vocational high schools (SMKN) which offer majors such as Information Engineering (Universitas Gadjah Mada/UGM), Information Engineering, Information Systems, and Computer Systems (Universitas Teknologi Yogyakarta/UTY), and many more. While the size of Yogyakarta is not as large as other provinces, its population is relatively large at 3.5 million people, with 32.38 percent of them being millennial (equivalent to 1.2 million people). However, Yogyakarta's income per capita is low. Yet, its HDI score is high among the sampled provinces, albeit still lower than Jakarta's.

The Provinces of South Sulawesi and North Sumatra are among the provinces 
where developments in the digital-based economy are beginning to be kindled as a result of improvements in infrastructure, advancements in HR quality, and millennial with the spirit to develop through utilizing the digital-based economy. South Sulawesi is one of the provinces outside the Java-Bali provinces which start to support digital-based economy. This is can be evaluated by several indicators such as government regulations, digital-related basic infrastructure, startup developments, and digital-related education. South Sulawesi's digital-related policies still lag behind in realizing the massive potential of the current digital developments; in the past eight years, the Local Government has issued only a few regulations on digital matters, such as those on the operation of post and communications, and the Pare-Pare Government master plan for information and communications technology. However, South Sulawesi has a high electrification ratio of 99.12 percent, though the percentage of its households accessing the internet is only 55.95 percent. With regards to developments in its digital-based ecosystem, the Province of South Sulawesi stands out as one of the provinces outside Java-Bali that is more digitally advanced, as evidenced by its 34 digital startups. South Sulawesi also has Incubators and Accelerators on par with those in Java, such as the Makassar Digital Valley (initiated by Telkom) and the Akademi Teknik Industri/ATI Business Incubator which operates 3D printing. In South Sulawesi, there are also a considerable number of co-working spaces spread across several areas. Finally, South Sulawesi's digital-related education is no less competitive than the other provinces in the sample. South Sulawesi has various digital-related majors such as Information Engineering (Universitas Hasanudin/UNHAS), Electronic Engineering Education (Universitas Negeri Makassar/UNM), Computer and Network Engineering (SMKN 2 Makassar). In general, South Sulawesi has sufficient capital to develop the digital-based economy in its region, with 33.54 percent of its population ( 2.8 million people from a total of 8 million people) being millennial. The province also has a relatively high GRDP per capita at 33.2 million Rupiahs, and a high HDI of 0.709.

The Provinces of Central Kalimantan and East Nusa Tenggara are among the provinces left behind in the development of the digital-based economy, as their infrastructure, human resources, and local governments are not yet supportive of the digital-based economy. The findings in Jakarta contrast starkly with the conditions in Central Kalimantan. It was found that Central Kalimantan is among the provinces with low digital readiness compared to other provinces in the research sample. The province of Central Kalimantan has, therefore, a digital-based economy that is lacking. This can be seen from several indicators involving government regulations, basic infrastructure, the development of the existing startup ecosystem, and digital-related education. In general, the regulations issued by the Local Government of Central Kalimantan related to digital matters in the past five years are fewer than those found in other sampled provinces. There exist only two regulations: one on guidelines for the operation the government's social media, and another on guidelines for the operation and monitoring of telecommunications. With regards to its basic infrastructure, Central Kalimantan's electrification 
ratio has reached 80.82 percent, while the percentage of households accessing the internet is only half of its population. Developments in the region's startup ecosystem are also behind; during field visits and interviews, the researchers were unable to find any digital startups originating from the province, and the Indonesian Startup Database reports the same. There also no incubators in the Central Kalimantan region. Finally, there does exist digital-related education in the province, but STMIK Palangkaraya is the only specialized higher education institution that offers majors related to digital matters. Hence, although Kalimantan Tengah is vast in land area among the sampled provinces, the potential of its digital-based economy remains underdeveloped. These findings are linked with the fact that the province's millennial population is only 36.92 percent of its total population and that the region's income per capita is relatively small. However, curiously, Central Kalimantan's HDI is relatively high at 0.704 , and its poverty rate of 4.47 percent is also low.

From the previous explanations, it can be seen that there exist inequalities between provinces in anticipating and responding to digital-based economic and its developments in Indonesia.

\section{Conclusion}

Developments in the digital-based economy in Indonesia, although somewhat lagging, are generally growing rapidly, particularly in Jakarta and large cities, in the provinces of Java and Bali. Indeed, out of the ten unicorns in ASEAN, four of them belong to Jakarta, with one of them, Gojek, having become a decacorn. This research finds that the rapid developments in the digital-based economies of Jakarta, Bandung, and Yogyakarta are supported by digitally-supportive infrastructure such as electricity and internet services, local government policies, and high-quality human resources. Meanwhile, in the provinces of Bali, North Sumatra, and South Sulawesi, digitally-supportive infrastructure and local government policies are not yet adequate, but its relatively high quality of human resources has allowed its digital-based economy to begin developing, although the number of emerging startups is still low. In the provinces of East Nusa Tenggara and Central Kalimantan, infrastructure to support the digital-based, is not yet adequate nor distributed evenly, the quality of human resources remains low, and local governments have not yet taken into consideration developments in the digital-based economy. Thus, it is understandable why there are not yet any startups originating from those two regions; however, even so, the digital-based economy has begun to emerge there, such as online taxibikes (ojek), Airbnb, AiryRooms, and entrusted shopping services (jasa titipan). If they are not swiftly addressed, the disparities in digital-based economic developments between regions in Indonesia can lead to exacerbated inequalities instead of bringing about the promised increase in prosperity through the creation of new jobs and more evenly distributed incomes. As such, the equalization of infrastructure as a necessary condition in the development of the digital-based economy must promptly 


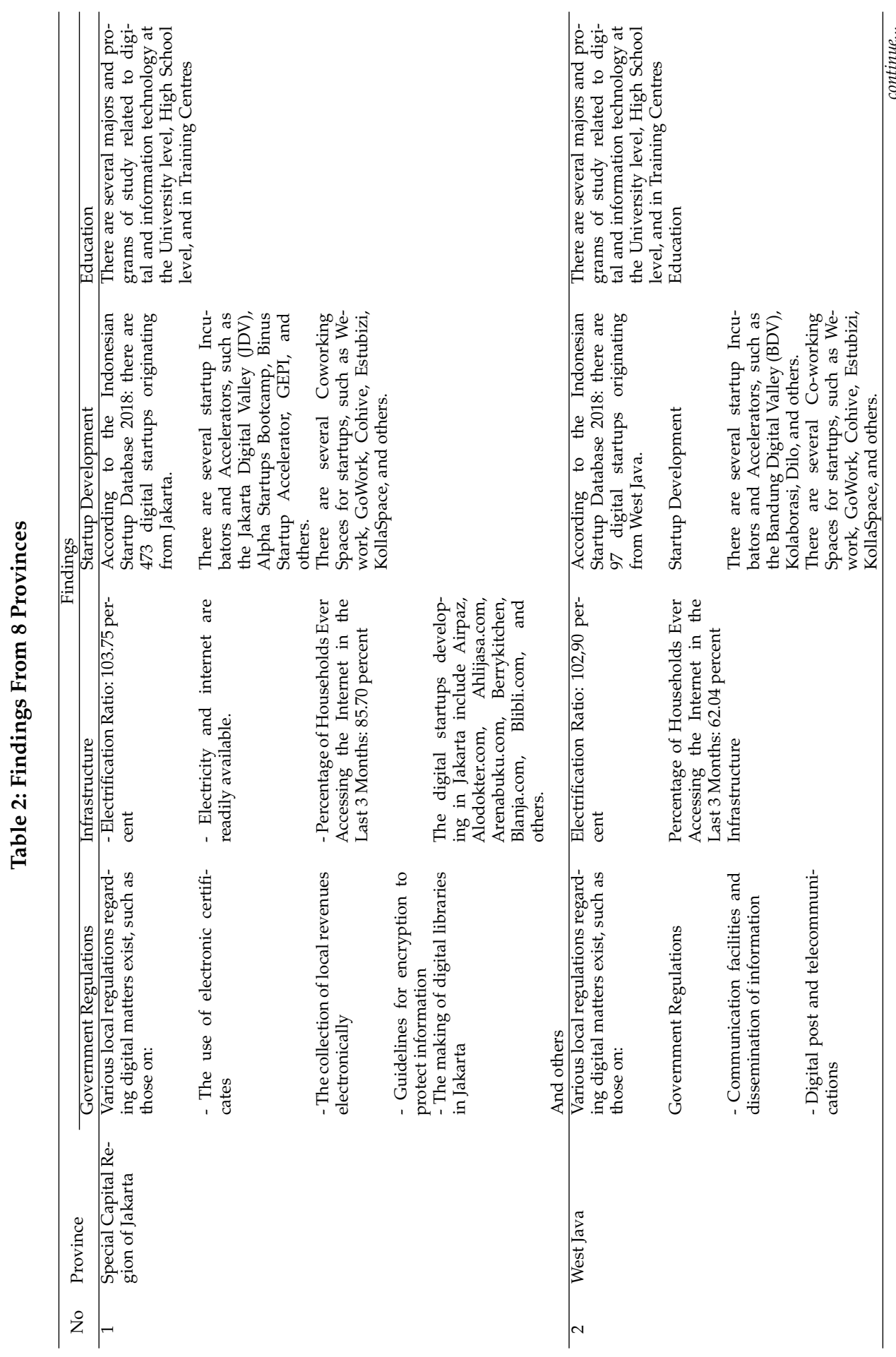




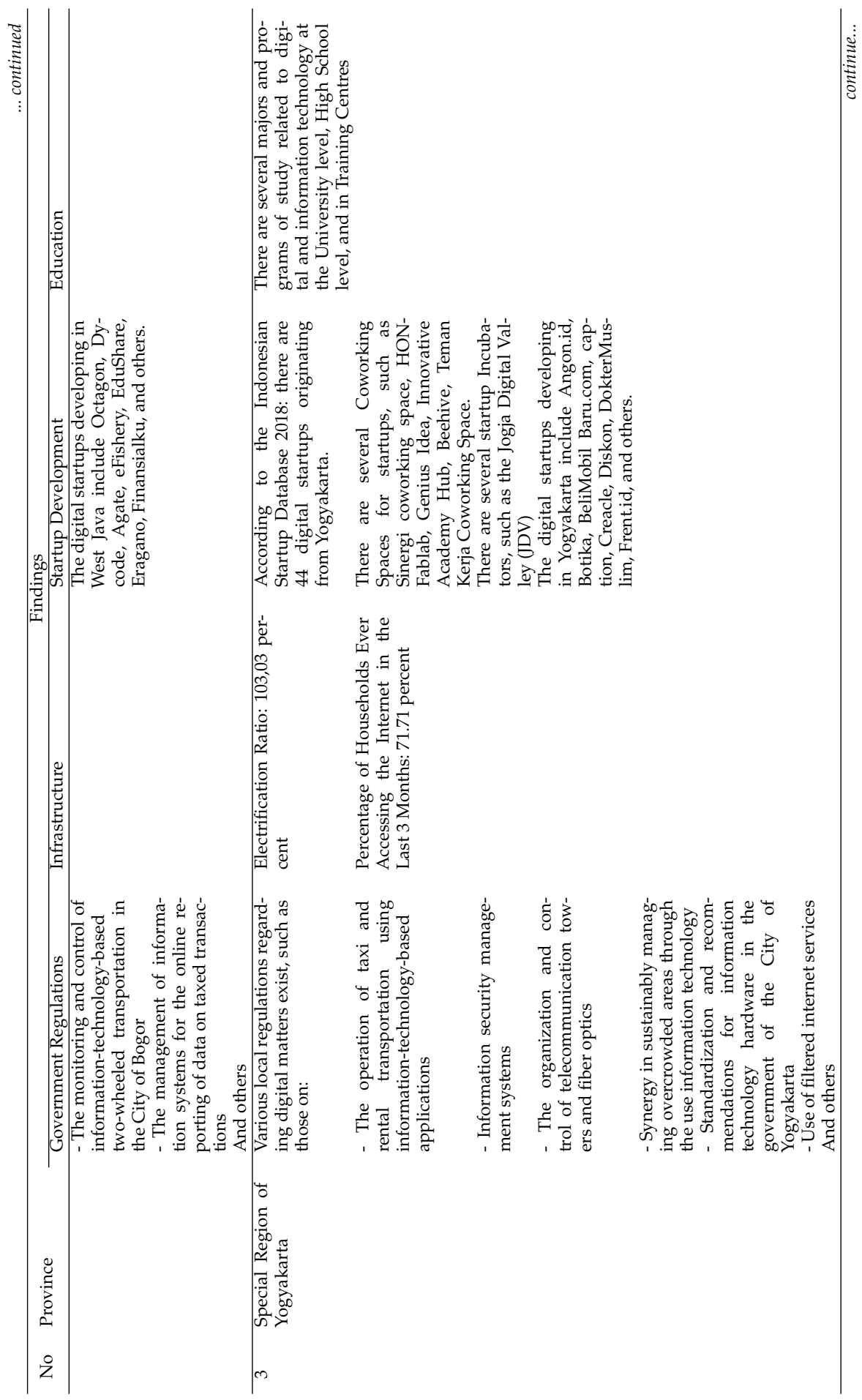




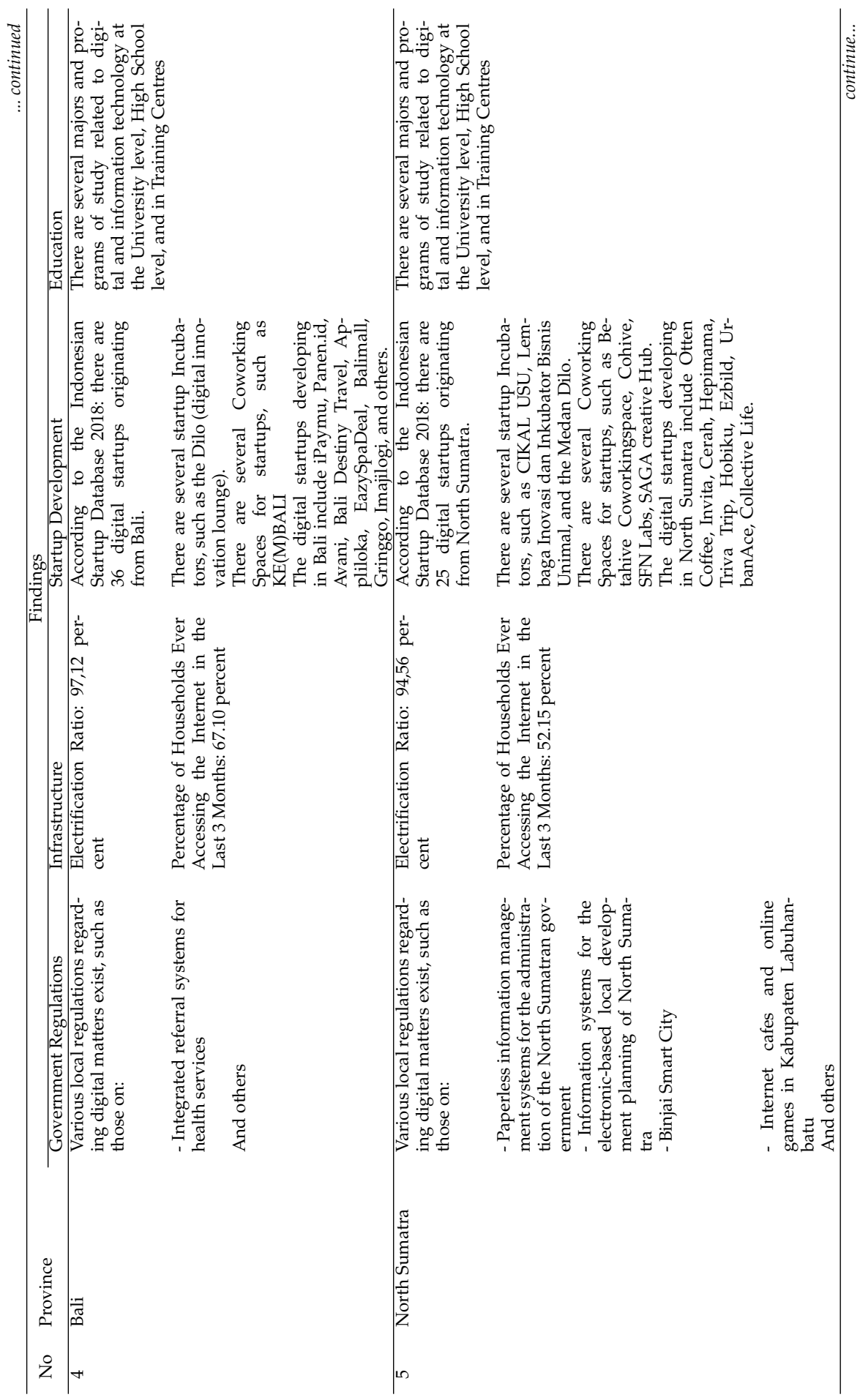




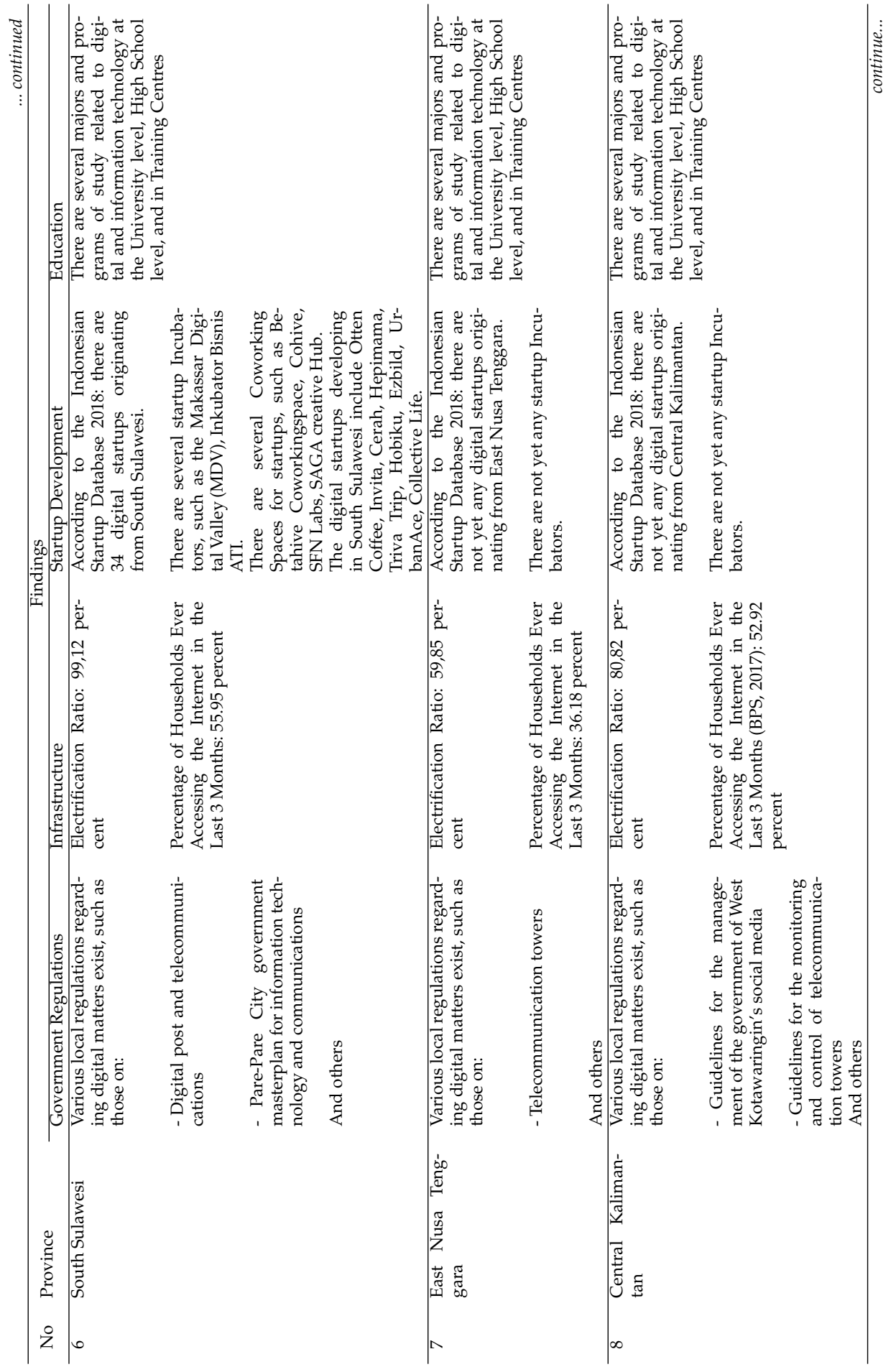




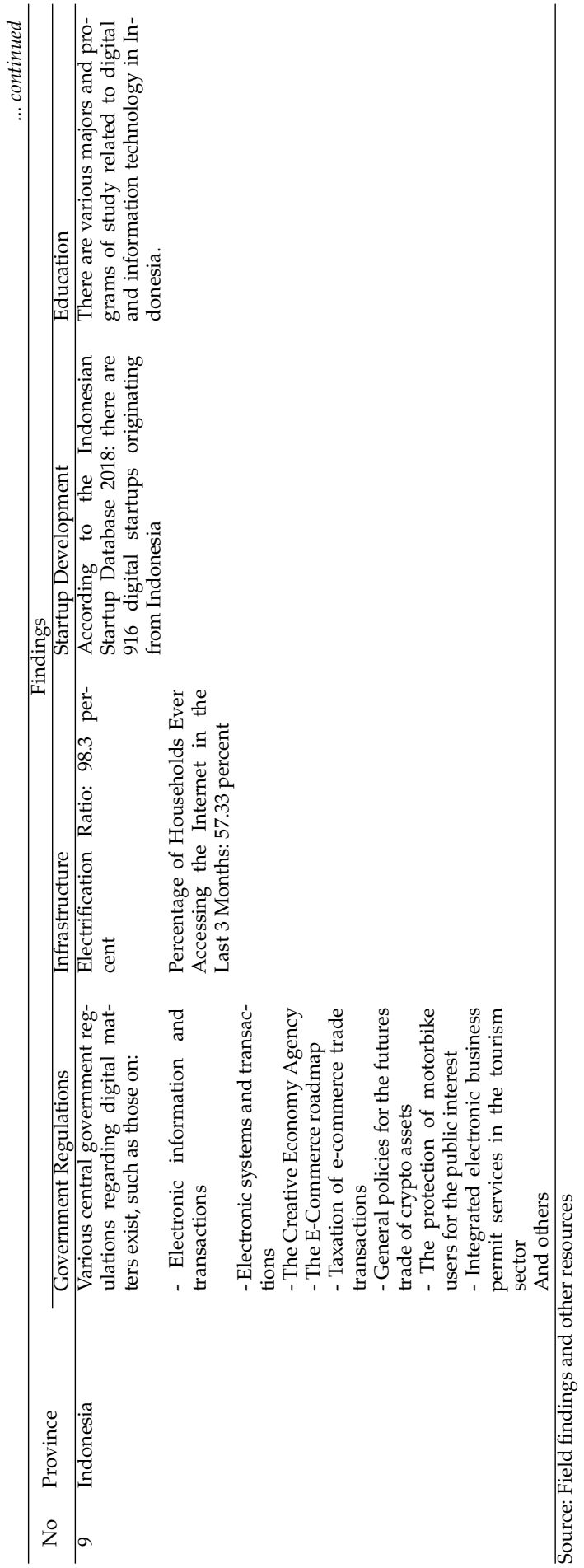


be handled. Additionally, both central and local governments must actively push, support, and facilitate developments in the digital-based economy, alongside the provision of programs and trainings to increase digital literacy so that people will be able to utilize the digital-based economy to improve their lives.

\subsection{Implication: Empowering the bottom of the pyramid}

In economics, the low-income group is sometimes referred to as the bottom of the pyramid, as there are more low-income individuals than those with middle and high incomes. In Indonesia, although the poverty rate continues to fall (reached 9.41 percent in 2019), however there are 90.25 million people living poverty or near poverty, 49.88 million of whom the majority live in remote rural areas (BPS, 2018). With the rapid transformation experienced today, measures must be taken to ensure that they are not left behind. One way to achieve that is to consider them as active members of society, and not merely as recipients of charity (Prahalad, 2009). They must be involved as active producers and consumers in the economy, especially the digital-based economy. While their individual buying power or productivity may not be huge, their large total number creates a considerable market.

Members of the low-income group can benefit as producers or employees in the digital economy in various ways. For instance, the current streamlining in the supply chain through various agribusiness startups can cut costs for small farmers, allowing them to reap greater profits. Informal businesses, even in the villages, can now reach the whole of Indonesia through e-commerce and social media, and can get additional funding from peer-to-peer lending. Informal food stalls (warteg) benefit from the extensive reach of the food delivery system. Moreover, there are numerous new kinds of occupations arising, including as financial technology agents and as freelancers. Both can be done even in the most remote locations with the presence of the internet. Meanwhile, on-demand services which are on the rise allow people to sign up as masseuses, handymen, car washers, house cleaners, and even pet washers.

Low-income people also benefit as customers. More businesses now serve their needs with the help of digitalization, allowing low-income people to more easily and cheaply purchase their needs. For instance, they no longer must spend time and transportation expenses to go to distant places to pay for their electricity or water bills; they can now use one of the numerous available fintech services to send money and pay bills without any charge. Furthermore, buying goods in remote areas can be cheaper as they now have access to a wider variety of competitive sellers from across Indonesia (and sometimes even from overseas) through e-commerce, as long as the logistic system is in place. Digitalization has also opened access to free online education and courses. Crowdfunding platforms can also be utilized to raise money when members of the low-income group require funds to build better schools, to pay medical expenses, or even to raise money to open a small business. 
Meanwhile, to ensure that the low-income group can realize and reap the gains from the digital economy, there needs to be synergy from all parties involved. The government can continue appreciating companies and non-profit institutions who work to empower the low-income community. The current development in providing electricity, better infrastructure, and internet and financial inclusion programs are a great catalyst. Both central and local governments can provide training for the low-income group on how to best take advantage of the digital-based economy. Businesses can provide training too, such as training on how to use digital to grow a business, especially for those working in niche markets serving the low-income group. Companies wanting to enter the market serving the low-income group must first understand their behavior, and knowledge can be shared on how best to serve them, likely with the help of some non-profit institutions.

All in all, the change is here, and it is here to stay. The question, then, is how to prepare and equip the vulnerable, such as those at the bottom of the pyramid, so that they are not left behind in this digital age.

\section{References}

[1] Adiningsih et al. (2019). Transformasi ekonomi berbasis digital di Indonesia. Jakarta: Gramedia Pustaka Utama.

[2] BPS. (2012). Penduduk Indonesia menurut provinsi 2010. Jakarta: Badan Pusat Statistik.

[3] BPS. (2016). Luas daerah dan jumlah pulau menurut provinsi, 2002-2016. Jakarta: Badan Pusat Statistik. Retrieved from https://www.bps.go.id/statictable/2014/09/05/ 1366/luas-daerah-dan-jumlah-pulau-menurut-provinsi-2002-2016.html.

[4] BPS. (2017a). Persentase rumah tangga yang pernah mengakses internet dalam 3 bulan terakhir menurut provinsi dan klasifikasi daerah, 2012-2017. Jakarta: Badan Pusat Statistik. Retrieved from https:/ /www.bps.go.id/dynamictable/2015/11/10/987/ persentase-rumah-tangga-yang-pernah-mengakses-internet-dalam-3-bulanterakhir-menurut-provinsi-dan-klasifikasi-daerah-2012-2017.html.

[5] BPS. (2017b). Produk Domestik Regional Bruto per Kapita Atas Dasar Harga Berlaku. Jakarta: Badan Pusat Statistik.

[6] BPS. (2018a). Indeks Pembangunan Manusia. Jakarta: Badan Pusat Statistik. Retrieved from https://www.bps.go.id/subject/26/indeks-pembangunan-manusia.html.

[7] BPS. (2018b). Percentages of poverty March 2019. Jakarta: Badan Pusat Statistik.

[8] BPS. (2018c). Perhitungan dan analisis kemiskinan makro Indonesia. Jakarta: Badan Pusat Statistik.

[9] BPS. (2019a). Persentase penduduk miskin. Jakarta: Badan Pusat Statistik.

[10] BPS. (2019b). Tingkat Pengangguran Terbuka (TPT) menurut provinsi. Jakarta: Badan Pusat Statistik.

[11] Direktorat Jenderal Kelistrikan. (2018). Statistik Ketenagalistrikan 2017 (Edisi No. 31Tahun Anggaran 2018). Jakarta: Kementerian Energi dan Sumber Daya Mineral. Retrieved from http://www.djk.esdm.go.id/pdf/Buku\%20Statistik\% 20Ketenagalistrikan/Statistik\%20Ketenagalistrikan\%20T.A.\%202018.pdf.

[12] IMD. (2017). IMD World Competitiveness Rankings 2017. New York: IMD World Competitiveness Center. Retrieved from http://www.otp.go.th/ 
uploads/tiny_uploads/PDF/2560-08/IMDReport/AppendicesAndSources / IMD_World_Competitiveness_Ranking_2017_Appendices_and_Sources.pdf.

[13] Kemenpppa. (2018). Profil generasi milenial Indonesia. Jakarta: Kementerian Pemberdayaan Perempuan dan Perlindungan Anak.

[14] McKinsey Global Institute. (2016). Unlocking Indonesia's digital opportunity. McKinsey \& Company. Retrieved from https://www.mckinsey.com/featured-insights / asia-pacific/unlocking-indonesias-digital-opportunity.

[15] McKinsey Global Institute. (2017, December). Jobs lost, jobs gained: Workforce transitions in the a time of automation. McKinsey Global Institute. Retrieved from https://www.mckinsey.com/ /media/McKinsey/Featured\% 20Insights/Future $\% 20$ of $\% 20$ Organizations/What $\% 20$ the $\% 20$ future $\% 20$ of $\%$ 20work $\% 20$ will $\% 20$ mean $\% 20$ for $\% 20$ jobs $\% 20$ skills $\% 20$ and $\% 20$ wages / MGI-Jobs-Lost-Jobs-Gained-Executive-summary-December-6-2017.ashx.

[16] McKinsey Global Institute. (2018). The digital archipelago: How online commerce is driving Indonesia's economic. Jakarta: McKinsey Global Institute. Retrieved from https://www.mckinsey.com/featured-insights/asia-pacific/ the-digital-archipelago-how-online-commerce-is-driving-indonesias-economicdevelopment.

[17] MIKTI. (2018). Mapping \& database startup Indonesia. Jakarta: MIKTI dan Bekraf.

[18] Neuman, W. (2014). Social Research Methods: Qualitative and Quantitative Approaches (7th Edition). Pearson, Essex, UK.

[19] OJK. (2016, December 29). POJK-Nomor-77-POJK.01-2016. Retrieved from https://www.ojk.go.id/id/regulasi/otoritas-jasa-keuangan/peraturan-ojk/ Pages/POJK-Nomor-77-POJK.01-2016.aspx.

[20] Prahalad, C. K. (2009). The fortune at the bottom of the pyramid. Wharton School Publishing.

[21] Tufts University. (2017). Digital planet 2017: Digital Evolution Index. Medford: The Fletcher School.

[22] WEF. (2016). Global information technology report. World Economic Forum. 